\title{
Tobacco control, global health policy and development: towards policy coherence in global governance
}

\author{
Jeff Collin
}

\begin{abstract}
Correspondence to Dr Jeff Collin, Global Public Health Unit, Social Policy, School of Social \& Political Science, University of Edinburgh, Chrystal Macmillan Building, 15a George Square, Edinburgh, EH8 9LD, UK; jeff.collin@ed.ac.uk
\end{abstract}

Received 31 December 2011 Accepted 8 January 2012

\begin{abstract}
The WHO Framework Convention on Tobacco Control (FCTC) demonstrates the international political will invested in combating the tobacco pandemic and a newfound prominence for tobacco control within the global health agenda. However, major difficulties exist in managing conflicts with foreign and trade policy priorities, and significant obstacles confront efforts to create synergies with development policy and avoid tensions with other health priorities. This paper uses the concept of policy coherence to explore congruence and inconsistencies in objectives, policy, and practice between tobacco control and trade, development and global health priorities. Following the inability of the FCTC negotiations to satisfactorily address the relationship between trade and health, several disputes highlight the challenges posed to tobacco control policies by multilateral and bilateral agreements. While the work of the World Bank has demonstrated the potential contribution of tobacco control to development, the absence of non-communicable diseases from the Millennium Development Goals has limited scope to offer developing countries support for FCTC implementation. Even within international health, tobacco control priorities may be hard to reconcile with other agendas. The paper concludes by discussing the extent to which tobacco control has been pursued via a model of governance very deliberately different from those used in other health issues, in what can be termed 'tobacco exceptionalism'. The analysis developed here suggests that noncommunicable disease (NCD) policies, global health, development and tobacco control would have much to gain from re-examining this presumption of difference.
\end{abstract}

\section{INTRODUCTION}

During the last decade, tobacco control has enjoyed a historically remarkable prominence within international health, a status epitomised by the extensive ratification of the WHO Framework Convention on Tobacco Control (FCTC), the first international public health treaty negotiated by the WHO. ${ }^{1}$ Yet the place of tobacco control within global health policy can also appear curiously uncertain. The FCTC was critical to Gro Harlem Brundtland's strategy for the renewal of the WHO during her term as WHO Director General (1998-2003), ${ }^{2}{ }^{3}$ yet tobacco-focused work received less than US $\$ 38.3$ million from WHO's 2006-2007 programme budget (less than one-quarter of that allocated to malaria and one-seventh of that for HIV/AIDS). ${ }^{4}$ Tobacco control's substantial potential to contribute to development was recognised by the World Bank, but it is excluded from the Millennium Development Goals, as are non-communicable diseases (NCDs) more broadly. And although the FCTC has been widely praised as a governance instrument and commended as a model for the control of other NCDs, ${ }^{5}$ WHO's recent global alcohol strategy ${ }^{6}$ diverges substantially from it, while a key architect of the FCTC now articulates a very different approach to regulating the food industry?

This peculiar mix of centrality and marginality reflects tensions between tobacco control and broader approaches to public health policy and global governance. Global governance refers to the 'worldwide transboundary interactions' of multiple actors among various policy levels' and recognises the increasingly influential roles of non-state actors. ${ }^{8}$ Global health is thereby seen as shaped by international organisations, transnational corporations and civil society, as well as nation states. While the FCTC demonstrates the substantial scope for innovative policy regimes to enhance tobacco control and health outcomes, significant challenges are posed by broader trends in governance of the global economy such as trade liberalisation and the promotion of foreign direct investment. ${ }^{9}{ }^{10}$ Effective tobacco control rests on a distinctively interventionist approach to regulating the conduct of specific corporate actors and is thereby very different from policymaking in most areas of public health. ${ }^{11}$ The FCTC implicitly sought to constrain transnational tobacco corporations ${ }^{12}$ at a time when $\mathrm{WHO}$ committed itself to much closer engagement with the commercial sector. ${ }^{13}$ Whereas tobacco companies are typically viewed as having interests that fundamentally conflict with public health, with Article 5.3 requiring their exclusion from the making of public health policy, ${ }^{14}$ other industries with substantial global health impacts (notably food and alcohol) are commonly viewed as appropriate partners in the development and delivery of health policy. ${ }^{11}$ The distinctiveness of tobacco control priorities by comparison with broader economic and foreign policy agendas was similarly evident in debates over the proposed inclusion of 'health over trade' language in the FCTC, in which widespread enthusiasm among developing country delegations and tobacco control advocates conflicted with the primary importance attached to trade liberalisation by high-income countries and international financial organisations. ${ }^{2} 1215$

Such distinctiveness and consequent tensions have important implications for strategies to counter the tobacco pandemic and for global health 
more broadly. These issues assume particular significance in the context of the United Nations High-Level Summit on NCDs in New York in September 2011. ${ }^{16} 17$ This paper seeks to explore the place of tobacco control within global governance and health policy and examine such implications using the concept of 'policy coherence' to assess congruence between tobacco control and other policy objectives. The term policy coherence connotes negative and positive senses. ${ }^{18}$ Its negative sense describes the absence of coherence or 'of inconsistencies between and the mutual impairment of different policies' while positive usage 'means the interaction of policies with a view to achieving overriding objectives'. ${ }^{19}$ The promotion of coordination across sectors has itself become a policy objective and indicator of successful governance, such that according to Lanzalaco, "the term 'integrated policy' has somehow become a synonym for "best policy". ${ }^{20}$

The promotion of policy coherence is an established concern within development studies, and has been defined by the Organisation for Economic Co-operation and Development (OECD) as requiring 'taking account of the needs and interests of developing countries in the evolution of the global economy'. ${ }^{21}$ In global health, interest in policy coherence has arisen primarily in efforts to reconcile health objectives with trade liberalisation, referring to the extent to which conflicts between policy agendas are minimised and synergies maximized'. ${ }^{22}$ The Bangkok Charter for Health Promotion presents the promotion of policy coherence across multiple levels of government, international agencies and with other actors, including the commercial sector, as able to 'strengthen compliance, accountability and transparency with international agreements and treaties that affect health'. ${ }^{23}$ The FCTC can itself be viewed as a tool to promote coherence across the multiple policy spheres relevant to tobacco control, requiring parties 'to develop and support, at the national, regional and international levels, comprehensive multisectoral measures and coordinated responses' and to establish a national coordinating mechanism or focal point for tobacco control. ${ }^{1}$

This paper will first explore the challenges posed for tobacco control by the limited congruence between its objectives and wider economic and foreign policy agendas, focusing particularly on tensions with trade agreements. It then considers the extent to which tobacco control has been integrated with the broader development policy agenda, before examining the difficulties experienced in maximising coherence even within health agencies. The paper concludes by discussing the extent to which tobacco control has been pursued via a model of governance that, in being based on the management of conflict of interest with corporate actors, has very deliberately differed from those used in other health issues. The analysis developed here suggests that tobacco control, NCD policies and global health and development more broadly would have much to gain from re-examining this presumption of difference.

\section{TOBACCO CONTROL AND GOVERNANCE OF THE GLOBAL ECONOMY: KEY TENSIONS}

Developments in economic governance are now recognised as enormously significant for global health, particularly in driving health inequalities. ${ }^{5}$ Debate has focused primarily on the health implications of multilateral trade agreements under the $\mathrm{WTO}^{24-27}$ and on the policies of financial institutions, including the World Bank and International Monetary Fund (IMF). ${ }^{28-30}$ Corporations have often been influential in shaping trade agreements, most notably in intellectual property rights ${ }^{31} 32$ and it has proved difficult to advance public health objectives within such fora. 2233

The contemporary prominence of global health has witnessed efforts by international organisations ${ }^{24}$ to demonstrate the extent to which health goals are consistent with economic, development and foreign policy priorities. In the 2007 Oslo Declaration, Brazil, France, Indonesia, Norway, Senegal, South Africa and Thailand 'agreed to make impact on health a point of departure and a defining lens that each of our countries will use to examine key elements of foreign policy and development strategies' ${ }^{34}$ A comparable initiative to promote coherence between tobacco control priorities domestically and internationally was announced by the USA, with the 1997 'Doggett amendment' aiming to end support of the tobacco industry by US overseas agencies. ${ }^{35}$ Reports of significant breaches of this commitment, ${ }^{36}$ its exemption allowing opposition to protectionist tobacco control measures 'which are not applied equally to all tobacco or tobacco products of the same type, ${ }^{37}$ and the tobacco industry's influence on US positions in FCTC negotiations $^{38}$ all highlight the challenge of achieving and sustaining substantive policy coherence.

The impacts of trade liberalisation in increasing tobacco consumption in low-income and middle-income countries are well established, ${ }^{9}{ }^{39}$ but the extent to which obligations under trade agreements constrain scope for effective tobacco control policies has long been debated. ${ }^{3540}$ The political ramifications of such disputes meant that the FCTC was unable to effectively address such tensions. Although its preamble acknowledges that 'the tobacco epidemic is facilitated through a variety of complex factors with crossborder effects, including trade liberalisation and direct foreign investment', the convention does not sufficiently address its relationship with these drivers. ${ }^{41}$ The ongoing significance of this omission is evident in the tobacco industry's expectation that it would have 'much to gain from the lowered import duties and streamlined trade administration' deriving from a completion of the WTO Doha negotiating round. ${ }^{42}$

The relevance of trade agreements to tobacco control policy is demonstrated by recent disputes within the WTO and under bilateral trade agreements, some two decades on from the landmark GATT adjudication in the Thai cigarette case. ${ }^{9} 244^{43}$ In September 2011, for example, a WTO dispute settlement panel reported its findings on a claim brought by Indonesia against the USA. $^{44}$ The panel found in favour of Indonesia's claim that Section 907 of the US Family Smoking Prevention and Tobacco Control Act prohibiting the production or sale in the US of cigarettes with a 'characterizing flavor' other than menthol or tobacco constituted trade discrimination against clove-based kreteks imported from Indonesia. ${ }^{44}$ Similarly, in June 2010 over 20 WTO member states expressed concerns about Canada's 'Cracking Down on Tobacco Marketing Aimed at Youth Act', claiming that its measures prohibiting tobacco products containing some flavourings and additives would effectively preclude traditional blended cigarettes and thus breach obligations under the Technical Barriers to Trade (TBT) agreement. ${ }^{45}$ Key fiscal measures of national tobacco control policies are also being contested. In July 2011, a panel rejected Thailand's appeal against an adjudication in favour of claims by the Philippines that several of Thailand's taxation, licensing and customs requirements discriminated against tobacco imports. ${ }^{46}$ Ukraine has requested a panel to review its claim that Armenia levies discriminatory internal taxes on imported tobacco products, imposing duties in excess of WTO obligations. ${ }^{47}$

WTO disputes attract particular attention within public health because the organisation's dispute settlement provisions 
can require countries to either revoke health measures deemed to contravene trade obligations or to accept the imposition of punitive sanctions. But it is arguable that the WTO actually offers a comparatively encouraging context within which to address tensions between health and trade objectives, given that WTO agreements acknowledge public health protection as a legitimate goal, incorporate significant flexibilities to accommodate this, and (potentially key for tobacco control) do not allow corporations to directly pursue legal action against states. ${ }^{24}$ Importantly, however, the primacy of the WTO within the global trade policy agenda is being eroded. The shift from the WTO to alternative fora, particularly bilateral trade agreements, ${ }^{48} 49$ can undermine public health protections afforded under WTO agreements, while bilateral and regional trade agreements increasingly include provision for investor-state disputes.

The potential significance of this shift is exemplified by a claim filed by three Philip Morris International (PMI) companies against Uruguay at the World Bank's International Centre for the Settlement of Investment Disputes (ICSID). A tribunal was established in March 2011 to assess PMI's claims that key provisions of Uruguay's tobacco control programme (requiring companies to sell only one pack variation per cigarette brand, mandating that health warning cover $80 \%$ of packaging and providing for graphic imagery in warnings) contravene obligations under a bilateral investment treaty between Uruguay and Switzerland. ${ }^{50-52}$ Similarly, in June 2011, PMI's Australian subsidiary announced it would challenge proposed plain packaging legislation, claiming that it would infringe Australia's bilateral trade agreement with Hong Kong. ${ }^{53}$

\section{TOBACCO CONTROL AND DEVELOPMENT: A LIMITED IMPACT ON PRIORITIES}

While the highly contested politics of trade and global health mean that such limits to policy coherence are perhaps unsurprising, it is also clear that international tobacco control objectives are not sufficiently reconciled with those of closely related agendas, particularly development. The negotiation of the FCTC made substantial progress in this regard, notably via the active engagement of the World Bank and its support for tobacco control as positive for development, and as likely to combine substantial health gains with enhanced government revenues for the majority of countries. ${ }^{54}$ This demonstration of cost effectiveness was key to the FCTC's successful negotiation. The success of WHO's African and Southeast Asian regions in shaping the FCTC agenda and engaging countries reliant on tobacco agriculture reduced tobacco companies' ability to plausibly depict tobacco control as a first world issue. ${ }^{2} 55$

Since the completion of negotiations, however, the consolidation of tobacco control within the wider development agenda has been at best partial. There has, for example, been limited progress towards economically and environmentally sustainable alternatives to tobacco growing under Articles 17 and 18. ${ }^{56} 57$ The United Nations' Global Compact, via which businesses can align with international commitments to human rights, labour, the environment and anti-corruption, has a policy of actively discouraging participation by tobacco companies. ${ }^{58}$ But this policy does not preclude such participation, and its membership includes Souza Cruz and ITC, dominant players in the cigarette industries of Brazil and India. ${ }^{59} 60$

Tobacco control's omission from the Millennium Development Goals (MDGs), within the wider omission of NCDs, has also been significant. While reducing tobacco consumption in developing countries could clearly contribute to achieving MDG objectives such as eradicating extreme poverty, reducing child mortality, improving maternal health and promoting environmental sustainability, ${ }^{61}$ strategies for attaining the MDGs have generally not been interpreted as entailing promotion of tobacco control or other NCD priorities. Tobacco control's exclusion from the core priorities of leading international health and development donor agencies has been seen as contributing significantly to the difficulties involved in securing adequate funding to support FCTC implementation in resource poor settings. ${ }^{62}$

Beyond this failure to maximise possible synergies, however, there remain issues and practices where the concerns of tobacco control and development actors diverge and are often still perceived as being in conflict. This is evident, for example, in arguments advanced within the WTO's TBT committee against Canada's recent measures on flavourings and additives. The delegations of Malawi, Kenya and Uganda submitted near identical documents alleging that this legislation "will have a negative effect on' their respective 'long term economic prospects' and create 'unnecessary obstacles to exports from developing country Members'. ${ }^{63-65}$

There have been attempts to promote policy coherence across UN agencies via the Ad Hoc Interagency Task Force on Tobacco Control, but the difficulties of attaining this are exemplified by the case of the Eliminating Child Labour Initiative (ECLT). This project, ostensibly aimed at the elimination of child labour in tobacco farming, is coordinated and funded by tobacco companies. ${ }^{66}$ ECLT was created by tobacco companies as a corporate social responsibility (CSR) initiative aimed primarily at improving their perception among elite and public opinion in high-income countries. ${ }^{67}$ The decision not to participate within it therefore seems fairly straightforward for tobacco control organisations given the industry's misappropriation of CSR. ${ }^{68}$ Viewed from within development, occupational health or child labour agendas, however, the health impacts of tobacco use are often peripheral to other concerns and cooperation with the tobacco industry may seem advantageous. In Kyrgyzstan, ${ }^{69}$ the International Labour Organisation (ILO), the UN Development Programme (UNDP) and UN Children's Fund (UNICEF) as well as Save the Children all participate in the ECLT's national steering group working alongside tobacco industry personnel. ${ }^{70}$ This challenge to policy coherence is similarly evident at the national level from the participation in ECLT of the Kyrgyz ministries of Labour, Rural and Water Management, and Employment and Migration. This participation has occurred despite the Ministry of Health identifying the absence of Article 5.3 from national law as the key barrier to Kyrgyzstan's implementation of the FCTC. $^{71}$

\section{TOBACCO CONTROL AND GLOBAL HEALTH: DISTINCTIVE MODEL OF GOVERNANCE}

This limited coherence between tobacco control priorities and development and foreign policy agendas is perhaps less surprising given the difficulties of attaining consistency even within health agencies. Such issues have been highlighted since 2007 by the case of the Instituto Carlos Slim de la Salud (ICSS). This major philanthropic initiative was founded by one of the world's richest men, Mexican businessman Carlos Slim Helú, and endowed with US\$500 million to focus on priority health issues in Latin America. Yet despite being lauded by the Bulletin of the WHO ${ }^{72}$ and an advisory committee of pre-eminent figures in international health, ${ }^{73} 74$ ICSS can be seen as the tobacco-funded gift of a leading industry figure. Slim's wealth has derived from his longstanding dominance of Mexico's tobacco industry and he remains a PMI board member. ${ }^{75}$ 
Such large-scale tobacco philanthropy poses a challenge to other health agencies, evident in the conduct of the Bill \& Melinda Gates Foundation (BMGF). In April 2010 BMGF withdrew its tobacco control funding from Canada's International Development Research Center (IDRC) citing conflict of interest after learning that IDRC's board chair was simultaneously a director of Imperial Tobacco Canada. ${ }^{76}$ Yet 2 months later, BMGF announced a 5 -year collaboration to reduce health inequities and support achievement of the health MDGs in Central America with ICSS as a key partner. ${ }^{77}$ Even within WHO, which has sought to create 'a complete firewall' between itself and tobacco companies, ${ }^{78}$ industry documents indicate that ostensibly independent scientists were used by Philip Morris to gain access to Thailand's scientific community, to influence research and teaching and develop relations with key officials via the Chulabhorn Research Institute (CRI), a WHO Collaborating Centre since December 2005. ${ }^{79}$

Tobacco control incorporates a model of governance that is clearly distinctive within global health and which strikingly differentiates it from broader trends in health governance, including approaches to managing other leading risk factors for NCDs. The launch of the FCTC as central to Brundtland's transformation of WHO here incorporates something of a paradox. Its negotiation constituted a de facto attempt to regulate the conduct and health impacts of transnational corporations, ${ }^{12}$ albeit crucially a distinctive subsection of the commercial sector, at a time when $\mathrm{WHO}$ was becoming reliant to an unprecedented extent on collaboration with corporations, particularly via global health partnerships to address infectious disease priorities. ${ }^{13} 80-82$

As exemplified by Article 5.3, the FCTC therefore embodies a commitment to rejecting the possibility of collaboration with the tobacco industry and an active policy of minimising interactions and policy engagement with it. When viewed from perspectives beyond tobacco control, this model can seem inconsistent with the widespread emphasis on promoting stakeholder participation that is seen as central to 'good governance' within international organisations, ${ }^{83}$ and very different to practices such as the ILO's emphasis on 'tripartism', by which employers' and workers' organisations should have an equal voice in policy development. ${ }^{84}$

The WHO's conception of the interests of the tobacco industry as antithetical to those of public health ${ }^{85}$ also differs from the positive potential attributed to collaboration with other industries with substantial health impacts. The FCTC is one of three foundations of WHO's wider approach to tackling NCDs alongside its Global Alcohol Strategy and Global Strategy on Diet, Physical Activity and Health. Notwithstanding the exceptionally aggressive opposition of the sugar industry during its development, ${ }^{86}$ the latter depicts the private sector as ' $\mathrm{a}$ significant player in promoting healthy diets and physical activity to the public' and the food industry as having an 'important (part) to play as responsible employers and as advocates for healthy lifestyles' and as a potential partner with governments. ${ }^{87}$ Despite broad calls from health groups for the adoption of an FCTC-like approach to alcohol regulation, 58889 the recent WHO global alcohol policy was developed in consultation with the alcohol industry and encourages it 'to consider effective ways to prevent and reduce harmful use of alcohol within their core roles mentioned above, including selfregulatory actions and initiatives' ${ }^{6}$ Such scope for self-regulation and potential for partnership with vectors of 'industrial epidemics 90 is now very difficult to reconcile with the tobacco control experience.

\section{CONCLUSIONS: PROMOTING POLICY COHERENCE BY MOVING BEYOND 'TOBACCO EXCEPTIONALISM'}

It would be inappropriate to exaggerate the extent of the incoherence in policy and practice between tobacco control and foreign policy, trade, development or global health governance more broadly, nor should the political commitment to reducing tobacco morbidity and mortality be underestimated. The FCTC process has incorporated a number of practices intended to actively promote policy coherence, including the establishment of multisectoral governmental committees during negotiations, ${ }^{12}$ the work of the UN's Ad Hoc Interagency Task Force on Tobacco Control, and the central role of legal, anti-fraud and customs and excise departments in the ongoing development of the Intergovernmental Negotiating Body on a Protocol on Illicit Trade in Tobacco Products. ${ }^{91}$ Crucially, moreover, the UN HighLevel Meeting in September 2011 offered a remarkable opportunity to redress the longstanding neglect of NCDs within development goals including health equity, poverty reduction and human security, with tobacco control being highlighted as the 'most urgent and immediate priority'. ${ }^{17}$

It must also be acknowledged that such variation in practice between tobacco control and other health goals has often been deliberate, with benefits in generating political will and driving policy innovation. What might be termed 'tobacco exceptionalism' was memorably captured by the observation of a WHO Committee of Experts: 'Tobacco use is unlike other threats to global health. Infectious diseases do not employ multinational public relations firms. There are no front groups to promote the spread of cholera. Mosquitoes have no lobbyists'. ${ }^{92}$ The tobacco epidemic has thus been portrayed as a unique threat to public health at national and international levels, with transnational tobacco corporations perceived as a pariah industry differentiated by conduct and product characteristics from other commercial actors.

Yet while tobacco products are clearly exceptional in the severity of their health impacts, (no other consumer product kills one in two users when used exactly as intended), ${ }^{85}$ there is little to suggest that the corporate strategies of alcohol or food corporations are inherently more conducive to positive health outcomes. ${ }^{119394}$ It is arguable that this exceptionalist imagery constitutes a barrier to the promotion of more substantial policy coherence in global health.

The relevance of 'tobacco exceptionalism' in perceptions of credible policy options at the international level was suggested by the Centre for Strategic and International Studies prior to the UN High Level Meeting on NCDs. While the FCTC was depicted as a model that could be broadly applicable across NCDs, the distinctive model of governance represented by Article 5.3 was rejected as inappropriate:

[T] he private sector, particularly the food and beverage industries, is extremely important to finding durable solutions. For that reason it is essential to include these industries in preparatory discussions... Here, the tobacco industry must be treated separately, given that there is no compromise possible over promoting a product that is implicated in over 8 million deaths per year (sic). However, there is a clear incentive, and interest, for the food and beverage industries to have a seat at the table and work toward a shared framework with target goals around both new norms and regulation. ${ }^{95}$

Such an analysis perhaps begs the question of how many annual deaths food or alcohol companies would need to be implicated in before partnership approaches would be deemed inappropriate. Since NCD epidemics are driven by the 
commercial activities of such industries, the extent to which their interests conflict with public health goals necessitates more serious examination of the exclusionary model of health governance successfully used in tobacco control. The scale of the challenge implied in extending such an approach is evident in the widespread concerns regarding the influence of food and alcohol companies preceding the UN High Level Meeting on NCDs. ${ }^{9697}$ While the prominence of the strong call for further implementation of the FCTC suggests that the summit's political declaration was positive from a narrow tobacco control perspective, ${ }^{98}$ the lukewarm response to the declaration and the absence of clear timetables and commitments to action 99100 indicate limited political will to confront the interests of alcohol and food companies.

Tobacco control itself could have much to gain from abandoning a presumption of its uniqueness in policy terms, integrating with broader public health and development agendas and learning appropriate lessons from their diverse experiences. For example, while the huge financial impetus provided by the Bloomberg and Gates foundations is unambiguously welcome, the experience of global health initiatives in infectious diseases suggests a need for caution in managing potential negative impacts such as distortion of national priorities, undermining local health organisations by recruiting key personnel, or inadequate governance practices. ${ }^{81} 82$ Conflict of interest provisions for tobacco control could also be strengthened by recognising that the fundamental conflict with the tobacco industry exists within a broader context in which corporate interests are unlikely to neatly coincide with those of public health. The role of pharmaceutical companies in the medicalisation of tobacco control $^{101}$ is a case in point. WHO's Tobacco Free Initiative programme manager recently warned of the need for tobacco control to preserve a distance from drug companies, noting that 'the tobacco industry is starting to joke that we have been sold to the pharmaceutical industry'. ${ }^{102}$ The scope for distortion of priorities is perhaps suggested by the 2009 FCTC global progress summary report, in which 'treatment of tobacco dependence and cessation of tobacco use ${ }^{, 103}$ was the most frequently cited priority and challenge for participating states, while strengthening price and tax measures did not appear in the top five areas cited.

Of course, concerns about the public health impacts of core features of the global political economy are not confined to tobacco control, and the opportunity to develop shared positions in contexts such as the UN is potentially significant. The presumption in favour of voluntarism in regulating the conduct of transnational corporations raises concerns in multiple sectors, and scepticism about reliance on CSR programmes to achieve social policy objectives extends far beyond tobacco control. ${ }^{5} 104$ The ongoing trade disputes outlined above suggest the need for the FCTC Conference of the Parties to take measures to advance understanding of the relationships between FCTC implementation, trade and investment agreements. ${ }^{105}$ The broader significance to global health of examining such relationships with key global governance instruments is suggested by the WTO TBT committee simultaneously hearing complaints against Canada's tobacco legislation and potential challenges to Thailand's requirements of specific health advisory statements and pictorial warnings on alcohol packaging, measures that had been introduced with specific reference to the tobacco experience. ${ }^{45}$

In providing a governance model for addressing diseases promoted via globalisation, tobacco control and the FCTC offer a potential route to addressing key failings in public health policies. Prioritising the regulation of corporate conduct can help

\section{What this paper adds}

The WHO Framework Convention on Tobacco Control (FCTC) reflects an unprecedented prominence for tobacco control within global health and a new salience within foreign policy. However, as the FCTC negotiations could not resolve the tensions that exist with trade agreements, limited progress has been made in establishing tobacco control among development goals, and tobacco control priorities and governance can be hard to reconcile with those for other health issues.

- This paper uses the concept of policy coherence to examine the extent of tobacco control's congruence with key economic, development and health goals. It suggests that insistence on the purportedly unique nature of the tobacco pandemic and conduct of the tobacco industry, termed here 'tobacco exceptionalism', limits scope for potentially productive synergies with other policy communities.

- The distinctive model of governance represented by the FCTC could have much broader application to global health, and is particularly important in the context of the UN High-Level Meeting on Non-communicable Diseases.

to counter 'lifestyle drift' in policies intended to address health inequalities, policies that often initially aspire to address social determinants 'only to drift downstream to focus largely on individual lifestyle factors' ${ }^{106}$ As a leading innovation in global health governance, the FCTC has already done much to counter what in the context of obesity Hawkes has termed the 'reluctance to tackle the more structural drivers of change'. ${ }^{107}$ The FCTC has acted as a counterweight to the extent to which international health priorities as defined in the MDGs have reflected the priorities of the wealthy. ${ }^{108}$

Positioning tobacco control within a more coherent approach to NCD governance offers a further opportunity to help redefine global health and development. NCD strategies can learn from the significance that tobacco control has attached to addressing conflict of interest with corporate actors whose economic interests diverge from those of public health, with Article 5.3 establishing a particularly valuable precedent. This implies rejecting partnership with food and alcohol industries as inappropriate and voluntary regulation as inadequate given the global challenge of obesity and alcohol related harms. Beyond such 'corporate vectors of disease', tobacco control can itself benefit from a broader recognition of the need to more carefully scrutinise the terms of relationships with those actors where health and commercial sector interests may partially coincide, including philanthropic organisations and pharmaceutical companies. The scale of the global burden of NCDs highlights the opportunity for major gains from increased policy coherence, but the recent UN declaration equally demonstrates the enormous advocacy challenge entailed in securing the political will necessary to realise that opportunity.

Funding $\mathrm{JC}$ receives research funding for tobacco document research from the National Cancer Institute of the United States, National Institutes of Health (grant number: 1R01CA160695-01).

Competing interests JC was part of a WHO Tobacco Free Initiative (TFI) Expert Committee convened to develop recommendations on how to address tobacco industry interference with tobacco control policy, and as such this travel to a meeting in Washington DC was reimbursed by WHO TFI.

Provenance and peer review Commissioned; externally peer reviewed. 


\section{REFERENCES}

1. World Health Organization. WHO Framework Convention on Tobacco Control. Geneva: WHO Press, 2003. http://whqlibdoc.who.int/publications/2003/ 9241591013.pdf (accessed 5 May 2011).

2. Collin J, Lee K. 'Globalization and the politics of health governance: the framework convention on tobacco control'. In: Cooper A, Kirton J, eds. Innovation in Global Health Governance: Critical Cases. Farnham, Surrey: Avebury Press, 2009:219-41.

3. Brown T, Cueto M, Fee E. The world health organization and the Transition from international to global public health. Am J Public Health 2006;96:62-72.

4. WHO Programme Budget 2008-09 Financial Tables. Table 5: Links Between Strategic Objectives 2008-2009 and Areas of Work 2006-2007. http://apps.who. int/gb/ebwha/pdf files/AMTSP-PPB/a-mtsp_7en.pdf (accessed 5 May 2011).

5. WHO Commission on the Social Determinants of Health. Closing the Gap in a Generation: Health Equity Through Action On The Social Determinants of Health. Final Report of the Commission on Social Determinants of Health. Geneva: World Health Organization, 2008. http://whqlibdoc.who.int/publications/2008/ 9789241563703 eng.pdf (accessed 5 May 2011).

6. WHO. Global Strategy to Reduce the Harmful Use of Alcohol. Geneva: WHO, 2010 http://www.who.int/substance abuse/msbalcstragegy.pdf (accessed 5 May 2011).

7. Yach D. Food companies and nutrition for better health. Public Health Nutr 2008;11:109-11.

8. Dingwerth K, Pattberg P. Global governance as a perspective on world politics. Glob Governance 2006;12:185-203.

9. Taylor A, Chaloupka FJ, Corbett M. The impact of trade liberalization on tobacco consumption. In: Jha P, Chaloupka FJ, eds. Tobacco Control in Developing Countries. Oxford: Oxford University Press, 2000:343-64.

10. Gilmore $\mathbf{A B}$, McKee M. Exploring the impact of foreign direct investment on tobacco consumption in the former Soviet Union. Tob Control 2005;14:13-21.

11. Gilmore AB, Savell E, Collin J. Public health, corporations and the new responsibility deal: promoting partnerships with vectors of disease? J Public Health 2011;33:2-4

12. Collin J, Lee K, Bissell K. Global health governance? The framework convention on tobacco control. Third World 0 2002:23:265-82.

13. Richter J. Public-Private Partnerships Health For All-How Can WHO Safeguard Public Interests. 2004. http://gaspp.stakes.decenturl.com/nr-rdonlyres-8f169cdc9a01 (accessed 3 Feb 2004).

14. World Health Organization. Guidelines for Implementation of Article 5.3 of the WHO Framework Convention on Tobacco Control on the Protection of Public Health Policies With Respect to Tobacco Control From: Commercial and Other Vested Interests of the Tobacco Industry. 2008. http://www.who.int/fctc/guidelines/ article 5 3.pdf (accessed 5 May 2011).

15. Mamudu H, Hammond R, Glantz S. International trade versus public health during the FCTC negotiations, 1999-2003. Tob Control 2011;20:e3

16. NCD. Alliance. A United Nations Summit on NCDs. http://www.ncdalliance.org/ node/51 (accessed 5 May 2011).

17. Beaglehole R, Bonita R, Horton R, et al; for the Lancet NCD Action Group and NCD Alliance 2011. Priority actions for the non-communicable disease crisis. Lancet 2011;377:1438-47

18. Carbone M. Mission impossible: the European Union and policy coherence for development'. J Eur Integration 2008;30:323-42.

19. Ashoff G. Enhancing Policy Coherence for Development: Justification, Recognition and Approaches to Achievement. Bonn: German development Institute, 2005. http:// www.die-gdi.de/CMS-Homepage/openwebcms3.nsf/(ynDK_contentByKey)/ENTR7BMHCF/\$FILE/Studies\%2011.pdf (accessed 25 Apr 2011).

20. Lanzalaco L. Bringing the olympic rationality back in? Coherence, integration and effectiveness of public policies. World Political Sci Rev 2011;7:1-27.

21. Organisation for Economic Co-operation and Development 2003. Policy coherence: vital for global development. Policy briefs, July. Cited: Carbone M. mission impossible: the European Union and policy coherence for development'. J Eur Integration 2008:30:323-42.

22. Blouin C. Trade policy and health: from conflicting interests to policy coherence. Bull WHO 2007;85:169-73.

23. World Health Organization. The Bangkok Charter For Health Promotion in a Globalized World. 2005. http://www.who.int/healthpromotion/conferences/ 6gchp/hpr 050829 \%20BCHP.pdf (accessed 11 Oct 2011).

24. World Health Organization, World trade organisation. WTO Agreements and Public Health: A Joint Study by the WHO and the WTO Secretariat. Geneva: WHO/ WTO, 2002. http://www.wto.org/English/res e/booksp e/who wto e.pdf (accessed 5 May 2011).

25. Labonte R, Schrecker T. Globalization and social determinants of health: the role of the global marketplace (part 2 of 3). Global Health 2007:3:6.

26. Blouin C, Bhushan A, Murphy S, et al. WHO commission on social determinants of health: trade liberalization: synthesis paper. Globalization Knowledge Network Research Paper 2007. http://www.globalhealthequity.ca/electronic\%20library/Trade \%20Liberalization\%20Synthesis\%20Paper\%20Blouin.pdf (accessed 5 May 2011).

27. Dollar D, Kraay A. Trade, growth and poverty. Econ J 2004;114:F22-49.

28. Wamala S, Kawachi I, Mpep BP. Poverty Reduction strategy papers: bold new approaches to poverty eradication or old wine in new bottles? In: Kawachi I, Wamala S, eds. Globalization and Health. Oxford: Oxford University Press, 2007:234-49.

29. Gilmore A, Fooks G, McKee M. The IMF and tobacco: a product like any other? Int J Health Serv Res 2009;39:789-93.
30. Stuckler D, Basu S, Gilmore A, et al. An evaluation of the international Monetary fund's claims about public health. Inter J Health Serv 2010;40:327-32.

31. Sell SK. Private Power, Public Law: The Globalization of Intellectual Property Rights. Cambridge: Cambridge University Press, 2003

32. Drahos P, Braithwaite J. Who owns the Knowledge Economy? Political Organising Behind TRIPS. Corner House briefing 32, September 2004. http://www. thecornerhouse.org.uk/sites/thecornerhouse.org.uk/files/32trips.pdf laccessed 5 May 2011).

33. Shaffer G. Recognizing public goods in WTO dispute settlement: who participates? Who decides? The case of TRIPS and pharmaceutical patent protection. J Inter Econ Law 2004; 7:459-82.

34. Ministers of Foreign Affairs of Brazil, France, Indonesia, Norway, Senegal, South Africa, and Thailand. Oslo ministerial declaration-global health: a pressing foreign policy issue of our time. Lancet 2007;369:1373-8.

35. Bettcher D, Shapiro I. Tobacco control in an era of trade liberalisation. Tob Control 2001;10:65-7.

36. Waxman H, Durbin R, Doggett L. Letter to the President. Washington, D.C. Committee on Government Reform, 2003. http://www.tobaccofree.org/treaty.htm (accessed 28 Apr 2011).

37. United States House of Representatives. Text of H.R. 2862 [109th]: Science, State, Justice, Commerce, and related agencies Appropriations Act, 2006 [Dogget amendment]. 2005. http://www.govtrack.us/congress/billtext.xpd?bill=h109-2862 (accessed 5 May 2011).

38. Waxman $\mathbf{H}$. The future of the global tobacco treaty negotiations. New Engl J Med 2002:346:936-9.

39. Chaloupka FJ, Laixuthai A. U.S. Trade Policy and Cigarette Smoking. In: Asia NBER Working Paper 5543. Cambridge MA: National Bureau of Economic Research, 1996.

40. Callard C, Chitanondh $\mathrm{H}$, Weissman $\mathrm{R}$. Why trade and investment liberalisation may threaten effective tobacco control efforts. Tob Control 2001;10:68-70.

41. Collin J. Global health, equity and the WHO framework convention on tobacco control. Glob Health Promotion 2010;17(Suppl 1):73-5.

42. Nuthall K. Trade benefits looming for tobacco. Tob J Int 2010. http://www. tobaccojournal.com/World Trade benefits looming for tobacco.50288.0.html (accessed 28 Apr 2011).

43. Trebilcock MJ, Howse R. The Regulation of International Trade London. 2nd edn. Milton Park: Routledge, 1999.

44. World Trade Organization. Dispute DS406 United States-Measures Affecting the Production and Sale of Clove Cigarettes. 2011. http://www.wto.org/english/ tratop_e/dispu_e/cases_e/ds406_e.htm (accessed 11 Oct 2011).

45. World Trade Organization. Technical Barriers To Trade: Tobacco And Alcohol Again Among Members' Trade Concerns, News Item. 2010. http://www.wto.org/ english/news_e/news10_e/tbt_23jun10_e.htm (accessed 28 Apr 2011).

46. World Trade Organization. Dispute Settlement: Dispute Ds371 ThailandCustoms and Fiscal Measures on Cigarettes from the Philippines. 2011. http://www.wto.org/english/tratop_e/dispu_e/cases_e/ds371_e.htm (accessed 11 0ct 2011).

47. World Trade Organization. Dispute Settlement: Dispute DS411 ArmeniaMeasures Affecting the Importation and Internal Sale of Cigarettes and Alcoholic Beverages. http://www.wto.org/english/tratop e/dispu e/cases e/ds411 e.htm (accessed 11 Oct 2011)

48. Globalization Knowledge Network. Towards health-equitable globalisation rights, regulation and redistribution - final report to the commission on social determinants of health. 2007. http://www.who.int/social_determinants/resources/ gkn final report 042008.pdf (accessed 11 Oct 2011).

49. Correa $\overline{\mathbf{C}}$. Implications of bilateral free trade agreements on access to medicines. Bull WHO 2006:84:399-404.

50. Peterson LE. Philip Morris files first-known investment treaty claim against tobacco regulations. 2010. http://www.iareporter.com/articles/20100303/print (accessed 05 May 2011)

51. Philip Morris International. Bilateral Investment Treaty Claim. Uruguay. 2010 http://www.pmi.com/eng/media_center/company_statements/pages/ uruguay bit claim.aspx (accessèd 29 Apr 2011).

52. International Centre for the Settlement of Investment Disputes. FTR Holding S.A. (Switzerland), Philip Morris products S.A. (Switzerland) and Abal Hermanos S. A. (Uruguay) v. Oriental Republic of Uruguay (ICSID case no. ARB/10/7) Case details Date of Constitution of Tribunal. 2011. http://icsid.worldbank.org/ICSID/FrontServlet (accessed 29 Apr 2011)

53. ABC News. Tobacco Giant To Challenge Packaging Laws. 2011. http://www.abc. net.au/news/stories/2011/06/27/3254069.htm (accessed 4 Jul 2011).

54. World Bank. Curbing the Epidemic: Governments and the Economics of Tobacco Control. Washington, D.C: Development in Practice Series, 1999.

55. Collin J. Tobacco politics. Development 2004;47:91-6.

56. Framework Convention Alliance. Briefing 8: The Study Group on Economically Sustainable Alternatives to Tobacco Growing (In Relation To Articles 17 And 18 Provision of Support For Economically Viable Alternatives and Protection of the Environment and The Health Of Persons), 2008. http://www.fctc.org/dmdocuments/ COP-3_policy_briefing_Articles\%2017_and_18_\%20Allternatives.pdf laccessed 5 May 2011)

57. Framework Convention Alliance. Policy Briefing: Financial Resources And Mechanisms of Assistance Fourth Session of the Conference of the Parties to the WHO Framework Convention On Tobacco Control, 15-20 November 2010, Punta 
del Este, Uruquay. http://www.fctc.org/images/stories/Policy\%20Briefing\%20-\% 20Finanical\%20resources\%20and.pdf (accessed 29 Apr 2011).

58. United Nations Global Compact. Tobacco Company Policy. http://www. unglobalcompact.org/HowToParticipate/Business_Participation/tobacco_company_ policy.html (accessed 1 May 2011)

59. Souza Cruz. 2010 Communication on Progress. 2011. http://www. unglobalcompact.org/system/attachments/9624/original/COP_SOUZA_CRUZ 2010 pdf?1300394958 (accessed 1 May 2011).

60. ITC. ITC Sustainability Report 2010. 2010. http://www.itcportal.com/sustainability/ sustainability-report-2010/sustainability-report-2010.pdf (accessed 1 May 2011).

61. Esson K, Leeder S. The Millennium Development Goals and Tobacco Control: An Opportunity for Global Partnership. Geneva: World Health Organization, 2004. http:// www.who.int/tobacco/publications/mdg_final_for_web.pdf (accessed 29 Apr 2011).

62. Framework Convention Alliance. Media Briefing: Tobacco Control and The Millennium Development Goals. COP-4/23, Uruguay. 2010. http://www.fctc.org/ images/stories/Media\%20Briefing\%20-\%20Tobacco\%20and\%20Development.pdf (accessed 29 Apr 2011).

63. Delegation of Malawi. The Effects of Canada's Tobacco Act on Malawi. World Trade Organization Committee on Technical Barriers to Trade G/TBT/W/329, 2010 http://www.wtocenter.org.tw/SmartKMS/fileviewer?id=108496 (accessed 3 May 2011).

64. Delegation of Kenya. The Effects of Canada's "Tobacco Act" on Kenya. World Trade Organization Committee on Technical Barriers to Trade G/TBT/W/330. 2010. http://www.wtocenter.org.tw/SmartKMS/fileviewer?id=110430 (accessed 3 May 2011)

65. Delegation of Uganda. The Effects of Canada's "Tobacco Act" on Uganda. World Trade Organization Committee on Technical Barriers to Trade G/TBT/W/331. 2010. http://www.wtocenter.org.tw/SmartKMS/fileviewer?id=110651 laccessed 3 May 2011).

66. ECLT Foundation. Eliminating Child Labour In Tobacco-Growing Country Partners. 2010. http://www.eclt.org/about-us/implementing-partners

67. Otañez MG, Muggli ME, Hurt RD, et al. Eliminating child labour in Malawi: a British American Tobacco corporate responsibility project to sidestep tobacco labour exploitation. Tob Control 2006:15:224-30.

68. Collin J, Gilmore A. Corporate (anti)social (ir)responsibility: transnational tobacco companies and the attempted subversion of global health policy. Glob Soc Policy 2002;2:354-60.

69. Samiev A. Policy Coherence In Public Health: Case Of Tobacco Control and Child Labour Elimination Policies in Kyrgyzstan. Unpublished dissertation, MSc Health Inequalities and Public Policy, University of Edinburgh, 2010.

70. ECLT Foundation. Kyrgyzstan Project Overview. http://www.eclt.org/projects-andprogress/kyrgyzstan/project-overview\#anchor2 (accessed 1 May 2011).

71. Kyrgyz Republic. Revised FCTC Reporting Instrument. 2008. http://www.who.int/ fctc/reporting/kyrgyz republic_report.pdf (accessed 5 May 2011).

72. Braine T. Mexican billionaire invests millions in Latin American health. Bull World Health Organ 2007;85:574-5.

73. Alleyne G, Aninat E, de Ferranti D, et al. Instituto Carso de la Salud: a boost for health philanthropy. Lancet 2008;371:100-1.

74. Chapman S. Group Carso, health philanthropy, and tobacco. Lancet 2008; 371:1243.

75. Burch T, Wander N, Collin J. Uneasy money: the Instituto Carlos Slim de la Salud, tobacco philanthropy and conflict of interest in global health. Tob Control 2010;19: e1-9.

76. Bill \& Melinda Gates Foundation. Statement Regarding IDRC Tobacco Control Grant. 2010. http://www.gatesfoundation.org/press-releases/Pages/statement-onidrc-grant-100412.aspx (accessed 3 May 2011).

77. Inter-American Development Bank. Bill \& Melinda Gates Foundation, Carlos Slim Health Institute, Spain, and the IDB Collaborate To Improve Health of the Poor in Mesoamerica. 2010. http://www.iadb.org/news-releases/2010-06/english/bill-andmelinda-gates-foundation-carlos-slim-health-institute-spain-and-the-idb-7317.html (accessed 16 Jun 2010).

78. United Nations Department of Public Information. Press conference on WHO Report on Global Tobacco Epidemic, 2008. http://www.un.org/News/briefings/docs/ 2008/080207 Tobacco.doc.htm (accessed 1 May 2011).

79. MacKenzie $\overline{\mathbf{R}}$. Collin J. "a good personal scientific relationship": Philip Morris scientists and the Chulabhorn research Institute, Bangkok. PLoS Med 2008:5:e238.

80. Italian Global Health Watch. From alma ata to the global fund: the history of international health policy. Soc Med 2008;3:36-48.

81. Buse K. Governing public-private infectious disease partnerships. Brown J World Aff 2004;10:225-42.

82. Buse K, Harmer A. Seven habits of highly effective global public-private health partnerships: practice and potential. Soc Sci Med 2007;64:259-71.
83. United Nations Economic and Social Commission for Asia and the Pacific. What Is Good Governance?. http://www.unescap.org/pdd/prs/ProjectActivities/ Ongoing/gg/governance.asp (accessed 5 May 2011).

84. International Labour Organization. Tripartite Constituents. http://www.lo.org/ global/About_the_LLO/Structure/tripartism/lang-en/index.htm laccessed 5 May 2011).

85. WHO Tobacco Free Initiative. Tobacco Industry And Corporate Responsibility. An Inherent Contradiction. 2004. http://www.who.int/tobacco/communications/ CSR report.pdf (accessed 5 May 2011).

86. Waxman A. The WHO global strategy on diet, physical activity and health: the controversy on sugar. Development 2004;47:75-80

87. World Health Organization. Global Strategy On Diet, Physical Activity And Health 2004. http://www.who.int/dietphysicalactivity/strategy/eb11344/strategy_english_ web.pdf (accessed 3 May 2011).

88. American Public Health Association. APHA Approves Framework Convention On Alcohol Control. Newsletter. Winter. 2007.http://www.apha.org/membergroups/ newsletters/sectionnewsletters/alcohol/winter07/alcoholcontrol.htm laccessed 3 May 2011).

89. Casswell S, Thamarangsi T. Reducing harm from alcohol: call to action. Lancet 2009:373:2247-57.

90. Jahiel RI, Babor TF. Industrial epidemics, public health advocacy and the alcohol industry: lessons from other fields. Addiction 2007;102:1335-9.

91. WHO FCTC Conference of the parties. Intergovernmental negotiating Body on a Protocol on Illicit trade. In: Tobacco Products. Fourth session. Geneva. 2010. FCTC/ COP/INB-IT/4/DIV./1 Rev.2. http://apps.who.int/gb/fctc/PDF/it4/INB4_DIV_1_Rev2. pdf

92. Zeltner T, Kessler DA, Martiny A, et al. Tobacco Company Strategies to Undermine Tobacco Control Activities at the World Health Organization. Report of the Committee of Experts on Tobacco Industry Documents. Geneva: World Health Organization, 2000

93. Bond L, Daube M, Chikritzhs T. Selling addictions: similarities in approaches between big tobacco and big Booze. Australasian Med J 2010;3:325-32.

94. Brownell KD, Warner KE. The perils of ignoring history: big tobacco played dirty and millions died. How similar is big food? Milbank 0 2009;87:259.

95. Sridhar D, Morrison JS, Piot P. Getting the Politics Right For The September 2011 UN High-Level Meeting on Noncommunicable diseases. Washington DC: Centre for Strategic and international studies, 2011. http://csis.org/files/publication/ 110215_Sridhar_GettingPoliticsRight_Web.pdf (accessed 25 Apr 2011).

96. Cohen $\overline{\mathbf{D}}$. Will industry influence derail UN summit? BMJ 2011;343:d5328.

97. Stuckler D, Basu S, McKee M. Commentary: UN high level meeting on noncommunicable diseases: an opportunity for whom? BMJ 2011;343:d5336.

98. UN General Assembly. Political Declaration Of The High-Level Meeting Of The General Assembly On The Prevention And Control Of Non-Communicable Diseases. A/66/L.1. 2011. http://www.un.org/ga/search/view doc.asp?symbol=A/66/L.1 (accessed 4 Oct 2011).

99. Coombes $\mathbf{R}$. World leaders sign up to tackle causes of non-communicable diseases. BMJ 2011;343:d6034.

100. Lancet Oncology. Two days in New York: reflections on the UN NCD summit. Lancet Oncol 2011;12:981.

101. Chapman S, MacKenzie R. The global research neglect of unassisted smoking cessation: causes and consequences. PLOS Med 2010;7:e1000216. doi:10.1371/ journal.pmed.1000216

102. Garcia Rada A. WHO Warns Anti-Smoking Campaigners Not To Become Too Close To Drug Firms.

103. WHO Framework Convention On Tobacco Control. 2009 Summary Report On Global Progress In Implementation Of The Who Framework Convention On Tobacco Control. FCTC/2009.1. http://www.who.int/fctc/FCTC-2009-1-en.pdf (accessed 1 Oct 2010).

104. Christian Aid. Behind the Mask: The Real Face Of Corporate Social Responsibility. 2004. http://www.st-andrews.ac.uk/ csearweb/aptopractice/Behind-the-mask. pdf (accessed 5 May 2011).

105. Framework Convention Alliance. Addressing the Relationship Between FCTC Implementation And International Trade And Investment Rules. COP-4/16 15-20 November 2010. Punta del Este, Uruguay. http://www.fctc.org/images/stories/ Policy\%20briefing\%20-\%20FCTC\%20implementation\%20and\%20international\% 20trade\%20and\%20investment\%20rules.pdf (accessed 3 May 2011).

106. Popay J, Whitehead M, Hunter DJ. Injustice is killing people on a large scale-but what is to be done about it? J Public Health 2010;32:148-9.

107. Hawkes C. Uneven dietary development: linking policies processes globalization nutrition transition, obesity diet-related chronic diseases. Global Health 2006;2:4.

108. Ollia E. Global health priorities-priorities of the wealthy? Global Health 2005:1:6. 